\title{
The Person and the Law: \\ Contingency, individuation and the subject of law
}

Baudoin Dupret

CNRS, CEDEJ

It is the inter-relatedness of the individual, the society and the structural categories of social relations which is at the heart of this book; law is simply the code by which the problems are stated. The question is quite naturally multidimensional. I shall explore three dimensions in this introductory chapter. First, I shall develop the subject of the contingent nature of the individual as a social and philosophical being. I shall then examine such relations as may be established between individual, social and political dynamics. Third, I shall examine the nature of the individual as a subject of law. Finally, I shall examine the interest that one might have in adopting a pragmatic approach to the observation of just how such a vast category of understanding evolves over the course of action, particularly legal action. In attempting to outline these various perspectives, the terms of the problem addressed by this book are stated rather than to attempt a solution.

\section{The category of the person}

Marie-Thérèse Meulders-Klein (1993: 436) makes the following observation: "as it has been defined, the notion of the person applied to Man conceived as a unique self, autonomous and equal by rights and dignity is self-evident. However, an historical or anthropological approach reveals there is nothing to it, either in time or in space. The concept of the person is not an 'innate category of reason', but the result of a long process linked to the adventure of Western Man, and remains ever subject to questioning". ${ }^{1}$

\footnotetext{
1 Meulders-Klein, 1993, p. 436.
} 
This proposition raises a number of questions which I would like to address in this section. The first deals with the category of the person and the relation of this category to those of the individual and the self. The second question concerns the contingent nature of this category and its historical antecedence. The third question deals with the ability to free oneself socially of such categories and thus of its transposability to other socio- historical contexts. Finally, a fourth question concerns the social markers of individuation and personalisation.

For all these questions, Mauss could conveniently serve as a point of departure ${ }^{2}$ as it did for the book edited by Carrithers, Collins and Lukes. ${ }^{3}$

For Mauss, it is a question of understanding how a category of the human spirit which one may presume innate, may be situated historically. Reasoning from Aristotelian categories, he observes the various forms taken by the notion in time and space. Asserting from the beginning that there has never been a human being who was not conscious, not only of his body but also of his spiritual and physical individuality, Mauss points out that he himself is primarily interested in the succession of forms assumed by this concept in the life of man within different societies. It is thus obvious that a large number of societies arrived at the notion of 'persona' or the role played by the individual in sacred theatre just as one would play a role in the family. For the Romans, however, the person becomes more than an organisational fact, more than a name or a right to assume a role and to wear a ritual mask: the person becomes a 'fundamental legal principal'. Law divides matter into personae, res and actiones, a classification which, he notes, remains the organising principal of our legal codes to this day. By this specific historic experience, law became personal and persona synonymous with the true nature of the individual. Mauss states that a moral dimension was added to the legal meaning: the idea of being conscious, independent, autonomous, free and

2 Mauss, 1985. 
responsible. Moral conscience introduces conscience into the legal concept of rights. One must, however, look towards Christianity for the transformation of the 'moral person' into a 'metaphysical being'. Here, one finds the transition from the notion of persona, which is man cast in a role, to the notion of Man, which is to say, the Person. It is because the notion of the moral person has become so clear that, in our times, it is applied to all non-real persons to whom we refer as 'moral persons': corporations, religious orders, etc. Finally, the notion of the person would have become the category of 'self"' through sectarian religious and reform movements concerned with individual liberty and conscience, with the right of the individual to communicate directly with God and to minister unto oneself as well as to have an internal god and, finally, through the influence of a philosophical movement for which the 'self' is the equivalent of conscience and constitutes the essential category. Fichte, in claiming that an act of conscience is an act of self, represents the culmination of this development. In this way, Mauss describes a grand evolutionary movement which from masquerade to mask, from persona to a person to a name to an individual, from the individual to a metaphysical being with a moral conscience, from moral conscience to sacred being and from sacred being to an essential figure of thought and action would culminate in this fundamental category of contemporary understanding.

Mauss makes a category of the person. From this point of view, he places himself in the tradition of Durkheim for whom the person is a "category of mind". This is one of those “essential notions which dominate our intellectual life like a "framework for understanding"”, and "which remain separate from all other knowledge both by their universality and by their necessity" which "are independent of any particular subject" and "constitute the point where all minds converge". ${ }^{4}$ He otherwise unites the notions of individual, person and self under a

\footnotetext{
3 Carrithers, Collins and Lukes, 1985.

4 Durkheim, 1912, pp. 9, 13.
} 
single concept. In Mauss' terms, 5 'the idea of 'person', the idea of 'self' (is) one of the categories of the human spirit - one of these ideas which we believe innate - which is slowly conceived and developed over many centuries and much adversity.

Confusion of these notions may seem problematic to those who, like Carrithers, ${ }^{6}$ distinguish between traditions which place emphasis on the person as a member of a group and traditions centred on the self which portray the human being as an individual and human beings within a spiritual cosmos. From this perspective, Mauss' approach would be personalistic and would confer a moral and cognitive value upon the group. Thus, if one observes the elevation of man, it would be as a part of a whole or as a 'self' made part of a person. Carrithers demonstrates the existence of totally different historical experiences. Following the thought process of a nineteenth century mystic, Anton Gueth, he reminds us of the extent to which German intellectual tradition is based on the individual and his conscience in relation to the group, based on a morality arising from the individual and not from the group.

Let us first note that the anthropological literature makes a clear distinction between the individual as a biological organism and the person as a system of social relations, the latter being the proper study of social anthropology. ${ }^{7}$ Two observations can then be formulated. On one hand, it would no doubt be useful to insist on the fact that Mauss, if one may consider his claim as normative that the cult of the Self is pathological - assuming the Self can evolve only in equilibrium with its social environment - makes no less a distinction between the person (classification arising out of Roman law) and the Self (a subsequent development arising out of religious and philosophical events). In this sense, for Mauss, the notion of self could arise

\footnotetext{
5 Mauss, 1950, p. 333.

6 Carrithers, 1985.

7 La Fontaine, 1985, p. 125.
} 
as a distinct development only after that of the person. The question arises as to whether such a sequence is contingent. On the other hand, it is interesting to distinguish between the Self and the Person in relation to the group. From this perspective, it should be noted that law looks first to the person as a member of the group, relegating the Self (which we might call "individual conscience" or "innermost being") to the domain of the non-legal or that for which his only option is to preserve integrity. This is clear from the very social nature of law and the difficulty of extending it beyond that which can be externalised or made public. At the same time, however, and such is the interest of Mauss' evolutionism: one may observe an ever stronger legal tendency to penetrate the inner person, to question motives and one's capacity for anticipation, of the expression of one's will, etc. Without doubt, the question deserves to be explored in depth, but at the very least, the question is posed here.

Mauss insists on the contingent nature of the category of the person which originates in a social context. At some point, it assumes forms which may be traced and, in modern times, has developed to become "self-evident". ${ }^{8}$ In other words, there exists a universal and necessary framework for thought about the person which takes different forms in different contexts. The framework developed by Mauss is, as summarised by Lukes, "fundamental, in that it is the basis for the rest of human thought; universal in that it is to be found in all human cultures, in different forms, even if these are misshapen or diminished; necessary in that beings, like ourselves, living in some recognisable form of society, cannot escape it". ${ }^{9}$ On this point, Mauss adopts a line of thought generally qualified as neo-Kantian. The categories are universal while their conceptualisation is contingent. In other words, what we observe today

\footnotetext{
8 Mauss, 1950, p. 334.

9 Lukes, 1985, p. 284.
} 
is the conceptual development of the category of the Person even though the category itself was implicit of a structuring and acting nature. ${ }^{10}$

Without doubt, we should make a pragmatic distinction here between the actual categorisation and the categories themselves. For the moment, we are focusing on the latter categories and, on this point, the contingent nature of the idea of the person does not seem disputable. As noted by La Fontaine, ${ }^{11}$ one must admit that different concepts of the person are written within a social context. From this point of view, it is perfectly possible to trace their paths which do not naturally reach their peak in the Western experience. At the same time, it is also possible to affirm the singularity of this experience and, for exact historical reasons, its tendency to go beyond its original geographic framework. If the West - and one must agree on this term - has not invented the concept of the person, it is nonetheless, the source of a concept which is identifiable and specific and whose influence can be traced beyond Western boundaries.

Thus, one may recognise the existence of a framework for thought contained simply within the universal existence of a "sense of self", of the consciousness that one may have of one's human body and of one's individuality - both spiritual and physical - but which consists above all in the fact that human thought cannot be structured without a notion of the individual in the biological sense. It can be, as it is for Taylor, ${ }^{12}$ a structure of feelings which are specific to human nature and which combine self-consciousness and valorisation (or significance). For Mauss, it is mostly a structure of beliefs, a set of very general beliefs underlying the various forms of law, religion, customs, social and mental structure, of a series of answers to very general questions on the distinctions between human persons and other

\footnotetext{
10 Collins, 1985.

11 La Fontaine, 1985, p. 138.

12 Taylor, 1985.
} 
conscious agents and on the relation between the individual and society, etc. This leads Mauss, as summarised by Lukes, ${ }^{13}$ to the description of the various situations:

Among the Pueblo, the person is seen as 'absorbed in his clan', yet already detached from it in ceremonial; among the Romans, 'persons' are both ritually linked to society and their ancestors and the bearers of rights, and, with the Stoics, come to acquire 'a sense of being conscious, independent, autonomous, free and responsible' (a consciousness which then entered the law); with Christianity and modern secular philosophy, 'the revolution in mentalities is accomplished' so that we are both social beings and bearers of 'metaphysical and moral value', indeed sacred beings.

From this perspective, to say that the person is a fundamental category is to assert the relation between thought and social structure, but it is also to encourage the interpretation of a culture's implicit and explicit ideas such as the translation of fundamental ideas and deeplyrooted structures. These ideas or theories can be explicit as is the case for specialists who devote their time to developing them. Thus, Carrithers describes Buddhism as "a decisive step in human thought about humans in relation to their mental and physical individuality". ${ }^{14}$ These ideas or theories can be implicit and consist in underlying postulates. Here, one finds for example, the contribution of Lafontaine who, in his comparison of four non-Western societies, makes the connection between indigenous psychologies and socio-political contexts. ${ }^{15}$

Mauss' outline definitely gives an impression of evolutionism which culminates in a modern world where the person has become "a sacred being, the possessor of metaphysical and moral value and of moral consciousness - the bearer of rights and responsibilities, the

13 Lukes, 1985, p. 287.

14 Carrithers, 1985, p. 253. 
source of autonomous motivation and rational decision, valuing privacy and capable of selfdevelopment". 16 This point of view, positively evaluating this evolution, thus once again normative, is definitely disputable. It has, in fact, many opponents. Following Lukes, ${ }^{17}$ one notes that, for Foucault, the individual in his modern version is an artificially built unit associated with the language of ethics and law; one may also note, that for Musil, the individual no longer has a clearly defined and historically understandable identity, that he is no longer the unifying focus of experience and a locus of personal responsibility. The fact remains that evolutionism, as opposed to determinism, does not constitute in itself one of the deadly sins of sociology. ${ }^{18}$ Furthermore, and for simple practical reasons, it is impossible to undertake research without recognising the necessity of certain common categories even if those are historical. The reference to the idea of person is one such category. From this point of view, reconciling concepts to objects with the effectiveness in the formulation of ideas, there exists a way of individualistic thinking that is characteristic of our contemporary societies which focuses on will, choice, evaluation and calculation: here, the individual thinks and acts - one might say "thinks of oneself" and "acts of oneself - as an autonomous agent in relation to others who are no less autonomous. ${ }^{19}$ Research is not spared this constraint.

Whether we like it or not, whether such an evolution is to be considered desirable, one must notice the impossibility of escaping from the modern notion of person, of individual and

15 Lafontaine, 1985.

16 Lukes, 1985, p. 294.

17 Lukes, 1985, pp. 294-295.

18 Elias notes that evolution, however intelligible, defies deliberate planning. Elias' evolutionism claims to be radically critical of the teleological reconstruction which is proper to the philosophy of historyand which, for him, is nothing more than metaphysics (Garrigou and Lacroix, 1997, p. 24). For Elias, evolution stems from an order which is both immanent change and void of any finality. It is a "progressive structure for which we can elaborate a model in which the succession, at first sight purely of facts and events, is organised in a comprehensible sequence" (Colliot-Thélène, 1997, p. 68 ) The question remains concerning the coherence of the elaboration of such a type of model. 
of self when one undertakes the study of the various forms of display. These concepts permanently affect our way of accounting for other ways of thinking. Once this is established, however, one may identify a number of markers of this modern thought and bring to light some of the characteristics of this distinctive process of modern thinking.

As examples, one can use, among many others related to such markers, a few recurring notions from Kantian and Freudian arguments such as autonomy, freedom, will, conscience and motive. Will, defined as the "capacity to freely determine whether or not to act" constitutes, with autonomy, one of the cornerstones of philosophy and modern epistemology. For Kant, the subject has become a causal principal of a certain force called action or intentional process. This suggests that the "subject represents a fundamental element, irreducible to any other element, transcendent or immanent. In other words, the subject, the Kantian 'cogito' is an autonomous element attributing a certain objectivity to the objects. The objects as such only become knowable in relation to the subject which precisely gives them a certain meaning, a meaning which is never definite in itself, but which is always the expression of the intentionality of the subject's actions and interactions". ${ }^{20}$ Freedom is also classically associated with the will: "the human being can only judge what is appropriate through the use of a faculty called 'will'; whereas the idea of will assumes the existence of other faculties by means of which it operates, especially freedom. We speak of freedom as the faculty by which will can express itself"' ${ }^{21}$ The legal principal of the autonomy of will, the very basis of contract law, probably best expresses the importance of this philosophical concept in law. In Gounot's words, "the individual is to be found at the foundation of the social and legal edifice, which is to say 'free will'. Freedom makes of the human being its own and only master; it makes him infinitely respectable and sacred; it raises him to the

\footnotetext{
19 Lukes, 1985, p. 298.

20 Stockinger, 1993, p. 48.
} 
dignity of an end in itself. Law is nothing other than this initial and sovereign liberty which belongs to all men. From free will everything comes; to free will everything returns". ${ }^{22}$ Will, autonomy, freedom and intentionality are thus the very foundations of the philosophical system of modern law and one immediately sees all the implications of this concept related to a subject acting freely and autonomously in terms of responsibility, imputation, premeditation, decision or judgement, all notions which are readily evident on the simple reading of the civil and penal codes.

\section{The process of individuation: the person, the society and the state}

We shall now integrate the category of the person in broader dynamics, associating the individual to society and power. Norbert Elias' writings are used as a basis for this chapter inasmuch as we deal explicitly with the development of the mental and socially-established state structures. Following our effort to define the nature, both contingent and universal, of the person as a category of thought, we establish the close relationship between its development and the emergence of a very specific process of political formation, the nationstate. ${ }^{23}$

Elias proposes a now classical model in which the phenomenon of monopolisation, otherwise synonymous with centralisation, which characterises the emergence of the

21 Pufendorf, as cited in Arnaud, 1993, p. 345.

22 Gounot, 1912, p. 27.

23 It is important to note that my reading of Elias is radically generous. What I mean by this is that the criticism of his evolutionism, his determinism, his psychologism and even his metaphysics of nature and of human nature are generally well founded (on this subject, see Ferrié, 2001). I believe, however, that Elias suggests a certain number of paths which, though he is far from following them, are nonetheless fertile. I am especially thinking about the relations between "small" (everyday life) and "great" (power) things. It is the path followed 
contemporary state, induces a progressive differentiation of functions and, subsequently, an increasing interdependence. One of the most attractive features of this thesis is the ability to associate interdependence and self-restraint, to show the extent to which, within a dynamics of relations restrained by a framework of complex interaction, the tendency is to elaborate codes of conduct to establish them as distinct signs, to progressively spread them, to share them and, finally, to internalise them - an ambiguous term incidentally - in the socialising process experienced by all individuals in society. These codes of conduct, these ethical codes are thus the result of increasing self-restraint which, for its part, expresses a distinct individuation. Individuality, interdependence and self-restraint are not so apparently opposed as their reciprocal condition: "the division and the differentiation of the mental functions of the human being expressed in the word 'individuality' are only made possible when the individual grows within a group of individuals, in a society". ${ }^{24}$ The individualisation, the cumbersome assertion of an individual conscience, the subsequent control of emotional reactions - all attitudes towards oneself and others - seem evident and natural and yet express "a very distinct historical imprint of the individual". The "individualised" individual, with an over developed 'self-conscience' is the individual forced by the society's constitution to adopt "a very high degree of restraint", to master his impulses and to submit to a code of ethics. "In a word, this 'self-conscience' refers to a structure of interiority which develops during welldefined phases of the civilising process. It is characterised by a clear differentiation and by a marked conflict between social constraints and proscriptions acquired and transformed into inner constraints, and the instincts and tendencies proper to the individual, untamed but contained". 25

by Schutz, Berger and Luckmann and by ethnomethodology (on this subject, see my article, "Forced Interaction: intersubjectivity, institutions and history", 2001).

24 Elias, 1991, p. 59.

25 Elias, 1991, p. 65. 
We would like to highlight some of the issues raised by Elias' thesis which are of particular interest to the problems addressed in this book; first, the correlation between changes in power structure and changes in individual and social behaviour; second, the connection between interdependence and self-constraint and, finally, the relation between the monopolisation of violence, state formation and legalisation of behaviour.

Several authors, first among whom Duerr, take exception to the idea of a progressive model in which, whatever may be the vicissitudes of evolution, society passes from impulsive behaviour to self-restraint. Using an impressive collection of examples and counter-examples, Duerr claims to prove that "the civilising process" is a myth obscuring the fact that, "in all probability in the last forty thousand years there have been neither wild nor primitive peoples, neither uncivilised nor unnatural peoples". ${ }^{26}$ Even if the theoretical demonstration seems superficial, the accumulated empirical evidence forces the question. Examining the question of modesty, Duerr asserts that rules governing the subject are an integral part of social relations.

For our part, we follow the analysis of Burguière, for whom, if one agrese with this supposition, one must at the same time note that these rules must be contextualised. The identity of uses through time and space does not, in any way, indicate a lack of change in the surrounding emotional and moral climates. In other words, concepts of the body may be universal concepts. However, one must, in any case, consider the extreme plasticity and variability with which identical conceptual and gestural models assume different forms and evolutionary paths in different societies. The question then becomes one of knowing how the same constituent uses of the body by the human species fit into each culture and how they structure society, given that culture is above all an act of memory, of selection, of

26 Duerr, 1998, p. 4. 
internalisation and of repression to the point of oblivion. The issue is to explore the means by which the individual appropriates the basic categories of self-perception and the perception of others to build his own system of regulation of interpersonal relations. On this subject, Elias' contribution is useful to the extent that it simultaneously explains the transformation of society and the person and seeks to account for the changes in scale in systems of power and social control. ${ }^{27}$

The main interest in Elias' thesis is the connection that he makes between changes in the structure of power and changes in individual and collective behaviour, what A. Dumont calls "the mechanism of social capillarity". ${ }^{28}$ Not only is individuality made possible "when the individual grows among a group of individuals, in a society", ${ }^{29}$ but one must also admit that States are social organisations whose formation is a social process as well ${ }^{30}$ and that, as such, their evolution is closely combined. Mental structures and state structures are so closely related that we must completely rethink the classical dichotomy between individual and society. In this process, we observe the establishment of new configurations which characterise both an era in its historical specificity and a society in its continuity.

In that sense, evaluating the importance of the "I" can only be done in a contextual, relational and evolutionary manner, evaluating a social configuration in which the individual inserts himself, a situation of interdependence which is both empirical and dynamic. ${ }^{31}$ In Elias' words, "the control of nature, social control and individual control are chained in a sort of circle; they form a functional trilogy whose vision can be used as a fundamental model for the observation of human problems; none of these elements can develop without the others;

27 Burguière, 1998.

28 As quoted by Burguière, 1997, p. 165.

29 Elias 1991, p. 59.

30 Elias 1991, p. 268.

31 Henry, 1997, 203. 
the measure and form of one depends on the measure and form of the others and if any of the three collapses the others will eventually follow." 32

Another important question raised by Elias' writings is the relation between specialisation, interdependence and self-restraint among individuals. Within the purview of this book, the question is no doubt relevant in order to understand the phenomenon of modern state formation, of the development of law, of the appearance of a new socio-professional category and of the legalisation of morals. Returning to Elias:

From the origin of Western history to this day, Elias says, we observe an ever increasing differentiation of social function under the growing pressure of competition. With this differentiation comes a continuous increase in functions and men, upon which each individual is entirely dependant, whether he accomplishes the most simple and ordinary tasks or the most complicated and unusual tasks. Thus, the behaviour of an increasing number of persons must be co-ordinated and interdependent acts must be organised more strictly and precisely so that each isolated act fulfils its social function. The individual has to differentiate, to control, assert and regulate his movements (...) Whether conscious or unconscious, the course of behaviour in relation to increasingly differentiated regulation of the mental apparatus, is determined by a greater social differentiation, by a division of function and by the lengthening chains of interdependence into which each movement, each expression of the isolated man is directly or indirectly integrated. ${ }^{33}$

32 Elias, 1991, pp. 189-190. On this point, we can legitimately think that Louis Dumont agrees with Elias when, on the subject of the philosophy of Herder, he demonstrates that his theory of cultures is a "national alternative" to the individualistic ideology and system of modern values (Dumont, 1983, p. 139). In other words, Dumont recognises the idea that a change in the prevailing structure and in its ideological representation has led to the transformation of the ways of thinking and acting.

33 Elias, 1975, pp. 185-186. 
The unconscious aspect of self-restraint may appear particularly questionable. This said, it can be understood as a phenomenon of privatisation of norms under the effect of pressure which leads to action in anticipation of the behaviour of others and of future situations. In a context of permanent social restructuring, new categories are regarded as different and this applies to a lengthening of the chain of interdependence linking the individuals. These new social positions pose "problems of type classification, and consequently of action" 34 and lead to the reinforcement of the individuation of control.

Elias' writings are also interesting in that they associate the monopolisation of violence and state centralisation with the internalisation of affects and with legislative intrusion.

The theory of a state monopoly on violence is old. It has been recognised by schools which were often radically opposed in their views, but which either recognise the idea that giving up the diffuse and private exercise of violence to benefit the exclusive exercise of the State characterises the transition from the state of nature to the state of law (Hobbes, Locke), the idea that sovereignty belongs to the representatives of the State which delegates its ability to give orders to the law-maker (Bentham) or the idea that the State is the sum of institutions of one group dominating the other and that law is the legal recognition of this inequality (Gumplowicz). Finally, one should recall that according to Weber, law proceeds from a human authority that is especially established to guarantee the validity of an order by its capacity to enforce respect or punish its violation. ${ }^{35}$

Elias goes further in linking the State monopoly on violence to the internalisation of affects. He does not describe a decrease in violence, but a change in its modes of expression; the intensification of the legitimate violence of the State-at-war is a response to the

34 Courty, 1997, pp. 167-168.

35 Weber, 1971, p. 33. 
intensification of the control of violence and of the rules of peace. ${ }^{36}$ To the compartmentalisation of violence is thus added its restrictive definition and a policy of concentration "concerned with separating controlled use from a slide towards loss of control", "attentively watching all points from which this shift could occur" and insisting "on all the techniques which make it possible to recover self-control". ${ }^{37}$ This is where we can bring up Elias' studies about sports but also more contemporary debates on the use of drugs, the consumption of tobacco and alcohol, the relationship with nature, the politically correct, etc.

The association of the monopolisation of violence with the internalisation of the affects makes it possible to summarise "a whole set of processes which contain violence within specific limits, which establish its legitimate origins which specify its condition of use, which mandate accepted enforcers to carry it out and which regulate the reactions of a population deprived of the right to exercise any form of violence. ${ }^{38}$ I would be personally inclined to say that the affects are never, as such, internalised, that, on the contrary, they are always revealed, made public and externalised and that their mode of externalisation is modified. It is thus the role of sociology to describe how this externalisation occurs in order to show its changes as well.

36 Defrance, 1997, p. 294.

37 Defrance, 1997, p. 296.

38 Defrance, 1997, p. 297. On this particular point, law must play a fundamental role and, in conclusion, we may underscore the extension of the field of regulations carried out by the legal process of codification. The fruit of this monopolistic and centralised element of power, the code is a system of rules put in writing to reinforce their imperativeness notwithstanding the question of their effectiveness. In that, it is different from the textbook on ethics which, because of its need to prescribe common practice, reflects instead on a loosening of restraint whose element of control moves away from the individual and opens a space for withdrawal (Bourguière, 1998, p. xxiii). Hence, the paradox of the norm which, when legal, increases the external control upon the individual and which, when ethical, increases his personal autonomy. The simultaneous reinforcement of these two phenomena can, in any case, appear specific to modern society where the monopoly of the legal system and the relegation of ethics to the "private sphere" go together. 


\section{The subject of law}

This third part intends to open discussion about the recourse to the lexicon of the person through law. It is, in fact, obvious that the legal context has appropriated a whole series of concepts whose organisation if not formulation itself originates in Kantian philosophy. As Meulders-Klein notes, "contrary to the statement that, in order to recognize the existence of the legal person law must draw on nature and biology, the notion of person, as a subject of law, far from being natural, is a cultural notion, and one of many forms of representation of the human being, dependent upon the condition of specific social structures, and independent of the universal aspect of the biological and psychological attributes of man". ${ }^{39}$

The biography of the category of the person is partly legal. As underscored by Rorty:

...our idea of person comes from two sources; the first is theater, the dramatis personae of the stage; the other is law. An actor wears masks, literally personae, through which the sound and the different roles come... So the person stands behind his role, chooses them and is judged on his choices and on his capacity to stage his personae within a global structure which is the unfolding of his drama. The idea of the person is the idea of a unified center of choice and action, that unity to which the legal and theological responsibility relates. After making a choice the person acts and thus is legally and morally responsible. It is in the idea of action that are gathered the legal and theatrical sources of the concept of the person. ${ }^{40}$

Thinking further, Rorty shows that:

39 Meulders-Klein, 1993, p. 437. 
it is only when the legal system gives up the notions of clan and family responsibility and that the individuals are considered as primary agents, that the class of persons coincides with the class of biological human beings. In principal, and often in law, this coincidence is not necessarily obvious. A given human being, while recognised as being an individual, can also be considered as having a whole series of personnae, each one a distinct and unified agent, a locus of responsibility for a wide scale of choice and action. ${ }^{41}$

Now, in terms of law, the concept of individual is dissociated from the concept of the person and the latter is not characterised by his identity to a biological human being, but by his quality as a subject of law and obligation. To refer to Locke (168: II, XXVII, § 26), "the term 'person' is a 'court term' [a forensic term]; this means that treating an individual as a person, is to consider him responsible for his acts before a court of law or of ethics, literally or figuratively - or even to some, before a court of divine judgement". ${ }^{42}$ At the same time, we should not fail to note that everyday language does not make a natural distinction between the individual and the person, but only a difference of degree, the person somehow being endowed with greater moral value. The individual has indeed been given, since the time of Guillaume d'Occam, the power to make laws. The individual has become the subject of law which is to say, the beneficiary "of a power recognised by positive law". As L. Dumont notes, legal nominalism, positivism and subjectivism expressed in such views signal the birth of the Individual in philosophy and in law: "When there is no longer anything ontologically real beyond a particular being, when the notion of 'law' relates, not to a natural and social order,

40 Rorty, 1976, p. 309.

41 Rorty, 1976, p. 309.

42 Locke, 1968, II, XXVII, § 26. 
but to a particular human being, this particular human being becomes an individual in the modern sense of the term." ${ }^{43}$

The philosophy of the autonomous subject and legal individualism undoubtedly proceeds from the same movement which ensures a central position for the person. Does that mean that the moral subject in philosophy and the subject of law in law are one and the same? To answer affirmatively would amount, no doubt, to an oversight of the autonomy proper to the legal argument and to its performative quality. Must we, on the contrary, claim that law is completely impervious and that its subject is then nothing more than a mere semantic artefact? This would also be excessive. The very fact that law is thoroughly influenced by the ideology of the individual cannot be totally foreign to the socio-historical establishment or modern legal activity while we must recognise the force of the constitution of its system. We are now at the core of a tangle of questions; this volume specifically addresses two of them. The first one concerns legal theories of the person which we are presented in the light of the differentiation between law and ethics. The second question deals with the legal conception of related notions and particularly with those of liberty, will, responsibility and intentionality (which goes back partly to previously developed arguments).

Here, we specially address the question posed by Ricœur; "who is the subject of law?" as well as consider the answers that the legal doctrine can give. The study of this debate which will most certainly continue that about the distinction between law and morals, has the advantage of revealing both the social and historical establishment of legal concepts and their ability to form an autonomous argument.

In his book Le Juste, Ricœur devotes a chapter to demonstrate that the legal question of the subject of law (who is the subject of law?) also relates back to a moral question (who is the

43 Dumont, 1983, p. 88. 
subject worthy of esteem and respect?) which, in turn, relates back to an anthropological question (what fundamental features make the self worthy of esteem and respect?). ${ }^{44}$ The question of "who" calls for identification from where comes the notion of "able subject". Posing this question is a matter of ascribing to someone an action or a part of an action. The attribution of the authorship of an act is fundamental in any imputation of rights and duties: it is the very core of the notion of capacity. Capacity, however, assumes the ability to distinguish between the good and the bad, between the permitted and the forbidden. A subject of accusation results from reflective application: "The subject of imputation is the result of the reflective application of 'good' and 'obligatory' predicates to the agents themselves". 45 Inasmuch as we are capable subjects, we can evaluate and judge our own actions. To be effective, this aptitude for self-esteem and self-respect requires the mediation of another, both personal (in relation to 'you') and institutional (in relation to 'they'). This is where, according to Ricœur the transition from capable subject to subject of law occurs: "Indeed, only the relation to a third party, placed in the background of the relation to the you, provides a basis for the institutional mediation required by the constitution of a real subject of law, in other words, of a citizen". ${ }^{46}$ One must master the relation to the "you" to be able to recognise the other as his equal in rights and duties, but one must also master the relation to the third party to be able to integrate a community of "speakers of a same natural language who do not know one another and are only related through the recognition of common rules which distinguish one language from the other". ${ }^{47}$ One then observes the outgrowth of the interpersonal relationship and the transition to the institutional relationship and to the social link which is well characterised by the use of the personal pronoun "each" so characteristic of modern legal language.

\footnotetext{
44 Ricœur, 1995.

45 Ricœur, 1995, p.32.

46 Ricœur, 1995, p. 34.
} 
To summarise, we shall say that Ricœur places the subject of law in a three-fold relationship to 'me' (individualism), to 'you' (interactionism) and to 'they' (institutionalism) which we may otherwise call the three poles of a non-metaphysical thought of the person.

What could the legal doctrine respond to this philosophical expression of the subject of law? According to Rommel, can identify three main legal theories on the subject in law which propose a continuum of visions going from the idea of a free and responsible person to that of an operational fiction breaking away from the biological and the social. ${ }^{48}$ Classical doctrine considers the subject of law as a pre-legal reality. This is in Hegel's line of thought for whom the subject of law is "the fulness of the human person in all its value, its dignity and its freedom". ${ }^{49}$ "Every human being is a person", say Aubry and Rau, and "every being capable of possessing rights and of submitting to obligations is a person, which implies then, that every human being is capable of possessing rights and duties. By analogy to the individuality of the physical person which is a work of nature, the concept of physical person was created, and "is only based on a legal abstraction". ${ }^{50}$ There is, then, a direct link between man and the legal person; law confers the latter quality to a being who already possessed it in a latent state. For Aarnio, "in the domain of law, the human being forms an important ontological category. He forms the category of subject of law". ${ }^{51}$ On this basis, the subject of law is the holder of subjective rights which is to say of legally protected interests.

Hans Kelsen's doctrine makes of the subject of law, a construct of the science of law which has no bearing in natural reality: "The physical person, in the sense of law, is not a man, but the personified entity of legal norms which impose legal obligations and confer

47 Ricœur, 1995, p. 35.

48 Rommel, 1999.

49 Rommel, 1999, p. 63.

50 Aubry and Rau, 1936, I, p. 305.

51 Aarnio 1987, p. 28. 
rights to a sole and unique individual". ${ }^{52}$ Subjective law is then reduced to objective law to the extent that the person is nothing more than "the personification of a system of legal norms" and to the extent that rights and obligations of the person are reduced to the legal norm "which punishes a certain behaviour of an individual and which subordinates the execution of the sanction to an appropriate legal action" 53 which relates back to Kelsen. ${ }^{54}$

The third doctrine radically dissociates man from the subject of law. Rommel refers to Althusser for whom the reference to natural man serves to present law as a natural and evident activity although it is nothing more than subjection. In Les Mots et Les Choses, Foucault, for his part, qualifies law as "semantic artefact". 55 Finally, for Teubner, the semantically artefactual nature of human actors constitutes one of the three main theses of the theory of an autopoeisis of law. ${ }^{56}$ If, as he says, "social institutions like law make the cognition of the individual a social matter", these same institutions "independently of the psychic process of their members" conceive of and create "independent worlds of meaning", "completely independent of the constructs of the legal world" whose mental constructs only function as 'disturbances'. If law, as a social process, "immediately and permanently confronts man", these, in fact, constitute little more than "semantical artefacts" which are both indispensable to and the fabrication of legal communication. Contrary to Kelsen, the systemic theory affirms the central nature originating with the subject of law, but legal subjectivity is constituted only of legal figures named and created by law:

It is at the cost of neglect of the legally constituted nature of the subject of law and of its avatars that the traditional doctrine gave law the appearance of a rooted place

52 Rommel 1999, p. 62.

53 Rommel 1999, p. 63.

54 Kelsen, 1962.

55 Foucault, 1966.

56 Teubner, 1992. 
in life, of a Sitz im Leben. The advent of the subject of law and of its functioning in the effectuation of law proves that law has no Sitz im Leben. The subject of law as articulated by law, does not exist in life, and human behaviour which makes up the content of rights and duties is nothing more than a legally created nomenclature for relations between the subject of law and the object of law, or to another subject of law (legal intersubjectivity), a relation named and simultaneously created by law with another legal concept. ${ }^{57}$

As for legal practice, it concentrates on the realisation of one of these figures through procedures which aim at its certification or at its falsification. In a word, "the physical or moral subject of law is not a pre-existing entity, but the original concept of law which makes possible all other legal concepts". ${ }^{58}$

The ultimate question, then, is who is the subject of law? We cite the two extremes of the answer, that of legal dogmatics which considers law in systemic terms as totally impervious to that which is outside of it and that of philosophical anthropology which seeks to place the law at the centre of the quest for justice. For the latter, "the subject is taken as the counterpart of law, its recipient, and not as the support or beneficiary (individual or collective) of positive rights" 59 which is the opposite of the dogmatic position that considers the subject as the condition, the means and the object of law. ${ }^{60}$ The question of the identity of the subject, essential for Ricœur, is irrelevant for Rommel who considers the subject as a simple abstraction necessary to the functioning of the legal proposition.

57 Rommel 1999, p. 67.

58 Rommel 1999, p. 68.

59 Ganty, 1999, p. 38.

60 Rommel 1999, pp. 69-70. 
On the question of capacity, these two views are complete opposites; the view of philosophical anthropology is that "the capacity of a human agent to designate himself as the author of his acts supposes that he is able to act intentionally, which is to say, by premeditation, and his capacity to initiate efficient changes in the course of things" 61 whereas the view of dogmatic systemics is that the legal fiction of intention allows law to act "as if" man and the subject of law were synonymous while only the act performed through the language of law is a legal act. This same capacity, which is a means of action for the philosopher (mastery of the rules of language, of self in the promise of agreement, of narration, etc. ) and an "inevitable connection to any legal recognition", ${ }^{62}$ is, in the opposite view, conditioned only by the enunciation of a legal proposition "which is to say, any proposition relating to a legal state of things (in law there is no other) and thus creating a legal rule". 63

There may be ways, not of reconciling but of repositioning these theses which would make it possible to position each argument at different levels of legal activity. It is, in fact, not obvious that the two antagonistic points of view apply to the same object, law. We would rather lean towards the idea of different perspectives (philosophy and dogmatics) applying to different objects (law as a legal issue and law as a product of speech). Legal dogmatics, however, do not exhaust the question of law. It is only an aspect of it, no doubt important, but just as certainly partial. Then, if it is dogmatically true that the fact only exists in law through its legal qualification, it is no less true that, cognitively and sociologically, this transition from fact of life to legal fact occurs a posteriori in the course of the judge's interpretation and never a priori in an operation where law would "dictate" what is the fact of law. In the same way, if a judge reads the law dogmatically, then, cognitively and sociologically, he can only

\footnotetext{
61 Ganty, 1999, p. 41.

62 Ricœur, 1995, pp. 34-35.
} 
construe the law in terms of law. From this point of view, it would be very useful to mention the thesis of Lenoble and Ost on the "mytho-logical" shift of legal rationality whose book dismantles the mechanics of perpetuating a logician's ideal in modern legal dogmatics. ${ }^{64}$ To say that law (and not only legal dogmatics) has no Sitz im Leben amounts to erasing the action which leads to the production of law as an institutional fact (cf. supra) for the benefit of systemic metaphysics. Many contemporary debates, however, tend to prove that the legal community (which does not consist only of dogmatists) gives a human substrate to the subject of law and gives a legal character to corporations and associations which operate by an analogy "which does not question the strict superposition of the human being and the subject of law, namely the analogatum princeps". ${ }^{65}$ The fact remains, however, that the human being whose legal activity is identified with the subject of law is not a simple biological being, but a certain conception and implementation of this biological being.

Individualism is, no doubt, at the core of modern law. Furthermore, legal individualism carries with it a specific conception of a series of notions related to that of the person as liberty, will, capacity, responsibility and intentionality.

Following Waline, to take only one example, we first note the extent to which "the Declaration of the Rights of Man (and of the citizen of 1789) is individualistic in its principle and evidently individualistic in its content". 66 This individualism embodies multiple ways: political, philosophical, legal, literary and economic. We shall note the emphasis placed on the free development of the personality, the priority given to the individual over society, the exclusion of any interference between the individual and the national community and the consecration of the right of property. From a legal point of view, this is expressed by the

63 Rommel, 1999, p. 74.

64 Lenoble and Ost, 1980.

65 Dijon, 1999, p. 53. 
constitution of the individual as "purpose of law and of all social institutions" as the unique holder of liberties. This exaggerated individualism, even if partially diminished later on, remains one of the fundamental characteristics of modern law and leaves a significant mark on the modern legal conception of the person. That person is declared free and from that individual freedom of man comes his ability to create law". ${ }^{67}$ In Gunot's words, "law is nothing but this initial and sovereign freedom which belongs to all men". ${ }^{68}$ A series of ideas follow, among them, the idea of fault and responsibility for fault. In criminal cases, the theory of free will was widely questioned where subjective situations are distinct from objective situations and, in cases of industrial accidents, where the no fault responsibility is recognised or in other cases where responsibility is founded on presumption. ${ }^{69}$ The fact remains that these distinctions originate in the model of the conscious individual gifted with will, acting intentionally, capable and thus susceptible to the consequences of his acts.

The theory of the autonomy of will originates in the nineteenth century under the influence of Katian philosophy. It claims that the restraining force of private legal acts originates primarily in the will of the authors of the act. This theory clearly rests upon the philosophical conception of the human being as master of his acts and, consequently, determines situations in which the act of an individual escapes his will (e.g. the theory of agreement irregularities). In the same way, there is a distinction between an agent contracting to accomplish legal acts and the same agent contracting to accomplish simple material acts. The will to contract implies the deliberate intention to obligate oneself while the violation of a contractual agreement does not imply the intention to engage one's responsibility, but has this

66 Waline, 1945, p. 376.

67 Savatier, 1959, § 356 .

68 Gunot, 1912, p. 27.

69 Arnaud, 1993, p. 346. 
responsibility as a consequence. ${ }^{70}$ If the original theory of the autonomy of will knows more and more limitations, we shall simply note that it remains a cornerstone in systems of civil law. So, the intention of the parties in contracting is fundamental in the law of obligations as well as in matters of civil responsibility. In criminal matters, the will of the author of an act determines its qualification and one must look to the evidence of the author's will and not merely to the material facts surrounding the act committed.71 And if, as in the law of responsibility, intentionality changes, it is not in the sense of its disappearance, but in the sense of its unlimited extension where the author of each act must keep in mind the infinite chain of the empirical consequences of his act.

Responsibility is a concept whose legal formulation is linked to liberal political philosophy and the civil code is one of its principal means of expression. Its appearance in the legal field is an obvious product of the Kantian philosophy of causality and imputation in which each one must consider himself as the unique and ultimate starting point of what happens to him. The field of responsibility is certainly a field where law and philosophy are closely intertwined. The notion of fault constitutes the junction between the two. We shall note the imminently moral nature of the latter. The theory of responsibility has considerably evolved, particularly in the twentieth century, and has not only been replaced in certain fields by a principle of solidarity and resulted in other fields in its disintegration (with the notion of risk in labour law, for example), but also determines the transition from a philosophy of individual fault to a philosophy of collective reparations. We speak of a crisis of responsibility "with as a starting point a shift in the emphasis previously placed on the presumed author of the damage and nowadays preferably placed on the victim who is in a position to demand reparations for

70 Rigaux, 1993, pp. 648, 649.

71 We shall note that the classical theory of Islamic law (fiqh) considers that the voluntary nature of homicide can only be established objectively with the proof that the instrument used to kill constitutes a weapon in itself (cf. Peters, 1990). 
damages"72 with the transition "from an individual handling of the fault to the socialised handling of risk". ${ }^{73}$ We shall note again with Ricœur the enormous paradox of a "society only concerned with solidarity in the interest of willingly reinforcing a philosophy of risk" and "the vindictive search for the guilty which amounts to the recrimination of the identified author of the damages", ${ }^{74}$ but of outrageous damages exceeding in a huge way the predictive abilities of the presumed guilty (as, for example, the contaminated blood scandal). Be that as it may, it is important to notice that this extension in space and this lengthening in time of the legal philosophy of responsibility does not work in the sense of a "dis-individuation", but in the sense of a reinforcement of the ability to predict and of interdependence which Elias precisely links to individuation. It is no longer only a matter of imputation of fault, but also initially of the demand for caution and precaution and down the road to a sense of responsibility for the potential effects of each persons' acts.

\section{Towards a pragmatic study of the person in context and in action}

This introduction is aimed essentially at exposing a certain number of theses, debates and postulates which the chapters in this book explain by using the example of the legal experience of Arab societies. This is why the question was deliberately dealt with in a general way.

We can therefore address the question of the person as a category of the law of various Arab countries across multiple levels. The perspective inspired by the sociology of Mauss is to study the historical and social dynamics which led the emergence of this category, this

72 Ricœur, 1995, p. 58.

73 Engle, 1993.

74 Ricœur, 1995, p. 59. 
"biographical" process describing in the end its present contents. In Norbert Elias' approach, the very principle of individuation growing in our societies lies in the association of the processes of differentiation, interdependence and self-restraint. However, in Luhmann's systemic manner, the emphasis is on the personality as the semantic artefact through which law gives a being, physical or abstract, or even a thing, the capacity to accomplish legal acts.

Finally, there is another pragmatic possibility where the category of the person is not dissociated from its use which is necessarily local, contextual and contingent. This, however, supposes the substitution of a praxiological approach which considers law and the legal person only in its practice to a sociology of great explanatory schemes.

As Watson points out, the notion of person and of "self" tends to be hypostatised. ${ }^{75}$ This affirmation of an autonomous or quasi-autonomous self, however, is contingent, as we have previously seen. Moermann thus shows that the Thai cultural context does not tend to reify a "self" who would be an agent thinking, planning, acting from within, no more than it tends to consider interactional events as the product of the action of multiple autonomous or quasiautonomous selves. ${ }^{76}$

In this respect, the theorisations of the persons alleged by the people, ordinary people or professionals of philosophy, do not necessarily constitute the model for "their actual practical, pre-theoretical use of their ordinary mental concepts and predicates". ${ }^{77}$ In other words, the notion of a singular and integrated "self" constitutes not an obscure and unexplained analytical resource, but the subject in itself of empirical investigation, the objective being then "to analyse the methodic practical use of whatever conception of self is employed by a

75 Watson, 1998.

76 Moermann, 1987.

77 Coulter, 1992, p. 249. 
collectivity". ${ }^{78}$ The person, the "me", the "self" then are not essences, ${ }^{79}$ but the constant interactional product of public "linguistic" resources displayed culturally which is to say contextually in a methodical manner. It is in and through conversation and other systems of language exchange (among them law) that character features - motivation, intention and rationality - or mental states - joy, fear, depression, suicidal intentions, hostility, etc. - are attributed to the person. "These imputations and ascriptions are, without exception, invoked on particular interactional occasions in order to make sense - culturally standardised, utterly practical sense - of a given action which is part of the conversation or is described within it, (or both). The 'nature and attributes of the self' are always methodically identified, defined, formulated and contested through action and interaction, i. e. they are constituted in the public domain and operate entirely as public, transparent phenomena." 80 It is now no longer a question of trying to identify the great social and historical dynamics, but of undertaking what Coulter (1992b) calls "a praxiological understanding of the "mental"”. ${ }^{81}$

\section{Abbreviations}

CEDEJ Centre d'Etudes et de Documentation Economique, Juridique et Sociale

CNRS Centre National de la Recherche Scientifique

LGDJ Libraire Générale de Droit et de Jurisprudence

78 Watson, 1997, p. 212.

79 Even though, for Mead, the origins and anchorage of the self are social and even though the self reflects the social process, it is a cognitive phenomenon, an inner dramatization of the external process. In Mead's work, there is an essentialism (Mead, indeed, writes of the 'essence of self' (Strauss, 1964, p. 228) and there is a parallel reification of the self/interaction boundary. Mead certainly does not fully transcend the 'internal-external' or 'self-interaction' distinction upon which a conception of such a boundary is based. The distinction is only mitigated, not abolished, by treating the self as the indwelling of the social process" (Watson, 1997, p. 214).

80 Watson, 1997, pp. 214-215.

81 Coulter, 1991. 


\section{Bibliography}

- Aarnio, A., The Rational as Reasonable, Dordrecht, Reidel-Kluwer, 1987.

- Arnaud, A. J., "Liberté", in A. J. Arnaud et. al., ed., Dictionnaire encyclopédique de théorie et de sociologie du droit, 2 edition, Paris, LGDJ, 1993, pp. 345-346

- Aubry, C. and C. Rau, Cours de droit civil français, Paris, Marchal and Billart, 1936.

- Boltanski, L. and L. Thévenot, De la justification. Les économies de la grandeur, Paris, Gallimard, 1991.

- Burguière, A., "Processus de civilisation et processus national chez Norbert Elias", in A. Garrigou and B. Lacroix, ed., Norbert Elias, la politique et l'histoire, Paris, La Découverte, 1997, pp. 145-165

- Burguière, A., "Entre sociologie et anthropologie: La civilisation des mours en procès", preface in H. P. Duerr, Nudité et pudeur. Le mythe du processus de civilisation, Paris, Ed. de la Maison des Sciences de l'Homme, 1998, pp. IX-XXI

- Carrithers, M., "An alternative social history of the self", in M. Carrithers, S. Collins and S. Lukes, ed., The Category of the Person. Anthropology, philosophy, history, Cambridge, Cambridge University Press, 1985, pp. 234-256

- Carrithers, M., S. Collins and S. Lukes, ed., The Category of the Person. Anthropology, philosophy, history, Cambridge, Cambridge University Press, 1985.

- Chartier, R., "Formation sociale et économie psychique: la société de cour dans le procès de civilisation", preface in N. Elias, La société de cour, Paris Flammarion, 1985, pp. I-XXVIII

- Chazel, F., "Emile Durkheim et l'élaboration d'un 'programme de recherche' en sociologie du droit", in Chazel F. and Commaille J., dir., Normes juridiques et régulation sociale, Paris, LGDJ, 1991, pp. 27-38

- Collins, S., "Categories, concepts or predicaments? Remarks on Mauss's use of philosophical terminology", in M. Carrithers, S. Collins and S. Lukes, ed., The Category of the Person. Anthropology, philosophy, history, Cambridge, Cambridge University Press, 1985, pp. 46-82

- Colliot-Thélène, C., "Le concept de rationalisation: de Max Weber à Norbert Elias", in A. Garrigou and B. Lacroix, ed., Norbert Elias, la politique et l'histoire, Paris, La Découverte, 1997, pp. 52-74

- Coulter, J., "Cognition: 'cognition' in an ethnomethodological mode", in G. Button, ed., Ethnomethodology and the Human Sciences, Cambridge, Cambridge University Press, 1991, pp. 176-195

- Coulter, J., "Bilmes on internal states: a critical commentary", Journal for the Theory of Social Behaviour, 22(3), 1992, pp. 239-252

- Courty, G., "Norbert Elias et la construction des groupes sociaux: de l'économie psychique à l'art de se regrouper", in A. Garrigou et B. Lacroix, ed., Norbert Elias, la politique et l'histoire, Paris, La Découverte, 1997, pp. 166-191

- Defrance, J., "Le goût de la violence", in A. Garrigou and B. Lacroix, ed., Norbert Elias, la politique et l'histoire, Paris, La Découverte, 1997, pp. 290-301

- Dijon, X., "Le sujet de Ricoeur: côté droit", in F. X. Druet and E. Ganty, ed., Rendre justice au droit. En lisant Le Juste de Paul Ricoeur, Namur, University Press of Namur, 1999, pp. 51-57

- Duerr, H. P., Nudité et pudeur. Le mythe du processus de civilisation, Paris, Ed. de la Maison des Sciences de l'Homme, 1998. 
- Dupret, B., "Intersubjectivity, Institutions and History: Remarks on Interaction and Constraint" (in Arabic), Mutûn 'asriyya fì'l-ulûm al-ijtimâ 'iyya, 2, 2001, pp. 44-52

- Dumont, L., Essais sur l'individualisme. Une perspective anthropologique sur l'idéologie moderne, Paris, Seuil, 1983.

- Durkheim, E., Les formes élémentaires de la vie religieuse, Paris, Alcan, 1912.

- Durkheim, E., "De la détermination du fait moral", Sociologie et philosophie, Paris, Alcan, 1924, pp. 49-116

- Durkheim E., La division du travail social, Paris, Alcan, $7^{\mathrm{e}}$ edition, 1960 (1893).

- Elias, N., La civilisation des moeurs, Paris, Calmann-Lévy, 1973.

- Elias, N., La dynamique de l'Occident, Paris, Calmann-Lévy, 1975.

- Elias, N., La société des individus, Paris, Fayard, 1991.

- Engel, L., "Vers une nouvelle approche de la responsabilité. Le droit français face à la dérive américaine", Esprit, June 1993, pp. 13-27.

- Ferrié, J. N., "The Thoughtless Interaction" (in Arabic), Mutûn 'asriyya fîl'-ulûm alijtimâ iyya, 2, 2001, pp. 53-58

- Foucault, M., Les Mots et les choses, Paris, Gallimard, 1966.

- Ganty, E., "Du sujet de droit au sujet du droit: attestation et reconnaissance", in F. X. Druet and E. Ganty, ed., Rendre justice au droit. En lisant Le Juste de Paul Ricoeur, Namur, University Press of Namur, 1999, pp. 37-49

- Garrigou, A. and B. Lacroix, "Norbert Elias: le travail d'une œuvre»", in A. Garrigou and B. Lacroix, ed., Norbert Elias, la politique et l'histoire, Paris, La Découverte, 1997, pp. 7-27

- Gounot, E., Le principe de l'autonomie de la volonté en Droit privé. Contribution à l'étude critique de l'individualisme juridique, Paris, 1912.

- Henry, C., "Eléments pour une théorie de l'individuation. Quand le domestique Mozart se prenait pour un libre artiste", in A. Garrigou et B. Lacroix (eds), Norbert Elias, la politique et l'histoire. Paris: La Découverte, 1997, 192-212

- Isambert, F. A., "Durkheim et la sociologie des normes", in Chazel F. and J. Commaille, dir., Normes juridiques et régulation sociale. Paris, LGDJ, 1991, pp. 51-64

- Jackson, B. S., Law, Fact and Narrative Coherence, Liverpool, Deborah Charles Publications, 1988.

- Jackson, B. S., Making Sense in Law. Linguistic, Psychological and Semiotic Perspectives, Liverpool, Deborah Charles Publications, 1995.

- Jackson, B. S., "Towards a semiotic model of professional practice, with some narrative reflections on the criminal process", International Journal of the Legal Profession, 1994, 1/1, pp. 55-79.

- Kelsen, H., Théorie pure du droit, Paris, Dalloz (tr. de Reine Rechtslehre, Vienna, Deuticke), 1962 (1934).

- La Fontaine, J. S., "Person and individual: some anthropological reflections", in M. Carrithers, S. Collins and S. Lukes, ed., The Category of the Person. Anthropology, philosophy, history, Cambridge, Cambridge University Press, 1985, pp. 123-140

- Lenoble, J. and F. Ost, Droit, mythe et raison. Essai sur la dérive mytho-logique de la rationalité juridique, Bruxelles, Publications of the Saint-Louis University Faculties, 1980.

- Locke, J., An Essay Concerning Human Understanding. Londres, Dent, 1968.

- Lukes, S., "Conclusion", in M. Carrithers, S. Collins and S. Lukes, ed, The Category of the Person. Anthropology, philosophy, history, Cambridge, Cambridge University Press, 1985, pp. 282-301

- Mauss, M., "Une catégorie de l'esprit humain: la notion de personne, celle de 'moi"”, Sociologie et anthropologie, Paris, PUF (extract du Journal of the Royal Anthropological Institute, v. LXVIII, 1938), 1950, pp. 333-361 
- Meulders-Klein, M. T., "Personne", in A. J. Arnaud et al., ed., Dictionnaire encyclopédique de théorie et de sociologie du droit, $2^{\mathrm{e}}$ ed., Paris, LGDJ, 1993, 435-438

-Moerman, M., Talking Culture, Cambridge, Cambridge University Press, 1987.

- Montefiore, A., "Identité morale", in M. Canto-Sperber, ed., Dictionnaire d'éthique et de philosophie morale, Paris, PUF, 1996, pp. 691-697

- Peters, R., "Murder on the Nile: Homicide Trials in $19^{\text {th }}$ Century Egyptian Shari'a Courts". Die Welt des Islams 30, 1990, pp. 95-115.

- Ricoeur, P., Le Juste, Paris, Esprit, 1995.

- Rigaux, F., "Volonté", in A. J. Arnaud et al., ed., Dictionnaire encyclopédique de théorie et de sociologie du droit, $2^{\mathrm{e}}$ ed., Paris LGDJ, 1993, pp. 647-649

- Rommel, G., "La nature du sujet en droit", in F. X. Druet and E. Ganty, ed., Rendre justice au droit. En lisant Le Juste de Paul Ricoeur, Namur, University Press of Namur, 1999, pp. 59-74

- Rorty, A., The Identities of Persons, Berkeley, University of California Press, 1976.

- Savatier, R., Les métamorphoses économiques et sociales du droit privé d'aujourd'hui. Approfondissement d'un droit renouvelé, Paris, 1959.

- Searle, J. R., The Construction of Social Reality, London, Penguin Books, 1995.

- Stockinger, P., "Autonomie", in A. J. Arnaud et al., ed., Dictionnaire encyclopédique de théorie et de sociologie du droit, $2^{\mathrm{e}}$ ed., Paris, LGDJ, 1993, pp. 47-49

- Strauss, A.L., Mead on Social Psychology, Chicago, University of Chicago Press, 1964

- Taylor, C., "The person", in M. Carrithers, S. Collins and S. Lukes, ed, The Category of the Person. Anthropology, philosophy, history, Cambridge, Cambridge University Press, 1985, pp. 258-263.

- Teubner, G., "Pour une épistémologie constructiviste du droit", Annales Economies, Sociétés, Civilisations 6, 1992, pp. 1149-1169.

- Veyne, P., Les Grecs ont-ils cru à leurs mythes? Essai sur l'imagination constituante, Paris, Seuil, 1983.

- Waline, M., L'individualisme et le droit, Paris, Domat Monchrestien, 1945.

- Watson, R., "Ethnomethodology, Consciousness and Self", Journal of Consciousness Studies, 5(2), 1998, pp. 202-223.

- Weber, M., Economie et société, Paris, Plon, 1971. 